\title{
Classic in Neuropediatrics
}

Medicine, in many of its aspects, is a science and as such striving for better understanding of the disorder of a patient, for a molecular clue or a new therapy. Therefore it is not surprising that much of our endeavours are geared towards progress. On the other hand, experience, a virtue created by an intricate mixture of knowledge, understanding and living through situations, is necessary for a good doctor, and even if for scientific reasons it is desirable to complement experience with evidence no patient would wish to be treated by a doctor whose experience is based on knowledge of the textbooks (or in modern days: guidelines) alone.

It is almost commonplace that with the advent of technology such as X-rays, followed by magnetic resonance imaging and even more sophisticated tools of molecular imaging the half life of what we can take for granted in our understanding is shrinking. Fifty years ago the father who had spent his life as a practitioner had a common platform of experience with his son who was going to take over. Nowadays, depending on your discipline, 10 years can make all the difference. And only imagine the questions your grandchildren will ask you. Molecular genetics and more recently the revolution of communication and data handling brought about by computer technology and the internet have further accelerated this process in which we are all taking part. In fact it is quite easy to predict that this novel structure of communication will not only change the media we are using but exert a deep influence on ourselves, on medical practice, and on the way we are communicating with our patients.

As a fast pace is imposed on us by the demands of our times and profession I found it timely to look back a little, into the last century so to say, and to shed a light in passing on some discoveries that were published in this Journal and helped to shape some collective experience. To put things into perspective we should be aware that over 130 years elapsed between the first description of what was to become "Duchenne" muscular dystrophy by
Dr. Edward Meryon in 1852 [8] and the discovery of the gene by Dr. Lou Kunkel and his group in 1987 [7].

Twenty-four years have passed since Dr. Pirkko Santavuori and colleagues from Helsinki (Fig. 1) first described nine children from Finland with a curious disorder which was characterized by hypotonia, eye dysgenesis, severe mental retardation and high CK levels. Due to the main organ involvement they termed this disorder "Muscle, Eye and Brain disease" [12]. A full paper describing the eye findings followed a year later [11], and the same group after 20 years of research pinned the gene locus down on chromosome $1 \mathrm{p} 32$ [4]. However, what was long thought of as a private disease restricted to Finland by a founder effect came to be unravelled by Japanese researchers who didn't have a single patient with this disease [13]. Thanks to the internet and accelerated communication, similar patients were quickly found in Asia and Europe. The culprit is a glycosylation enzyme with the unspeakable name of $\mathrm{O}$-mannose $\beta-1,2-\mathrm{N}$-acetylglucosaminyltransferase, no more user-friendly abbreviated to POMGnT1, how grateful are we to Dr. Santavuori for the comprehensible designation of what she described. As every answer is carrying at least one question with it, it remains to be determined if in future muscle-eye-brain disease will be classified in the textbooks as a muscular dystrophy, according to its historical nature, or as a congenital disorder of glycosylation, its biochemical nature. I dare predict that at least the historical name shall survive due to our limited verbal abilities.

In 1981, Dr. Uta Burck (Fig. 2) and colleagues described "Neuromyopathy and Vitamin E Deficiency in Man" in a 12-year-old boy with prominent ataxia [3]. They also noted that two cousins who were related both from the maternal and paternal side in this multiply consanguineous pedigree had died from presumably the same disorder at ages 18 and 23 years. The multiple lipopigment depositions were thought to be morphological sequelae of a long-standing, unexplained vitamin E deficiency, and the 


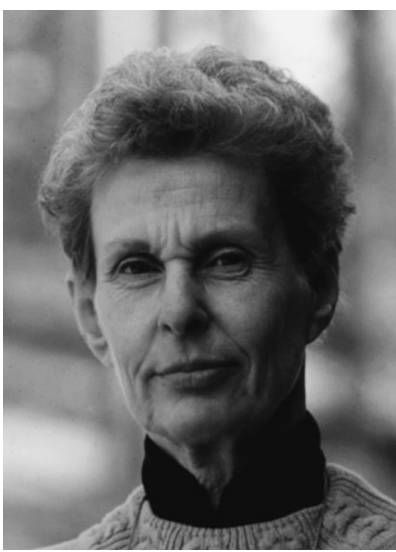

Fig. 1 Dr. Pirkko Santavuori.

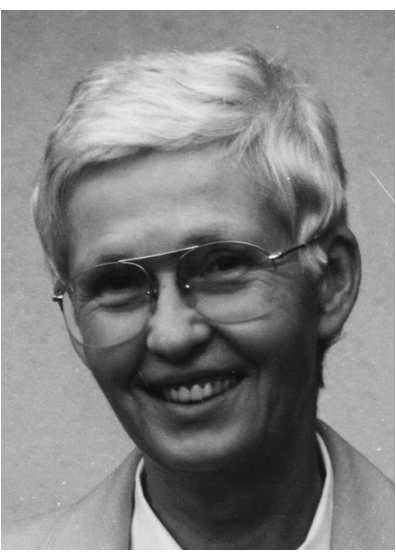

Fig. 2 Dr. Uta Burck-Lehmann. patient was supplemented accordingly. Another four years and several observations later the late Dr. Anita Harding concluded that vitamin E deficiency and ataxia represented an entity [5] which was subsequently explained by the discovery of mutations in the $\alpha$-tocopherol transfer protein in these patients [10]. The astute observations of Dr. Burck and colleagues serve to illustrate the fact that we can sometimes help even in the absence of more profound understanding of the specific pathophysiology but also that every neurodegenerative disorder deserves to be thoroughly investigated even if the intention to treat is not the primary hope and motivation.

While a "Classic" took centuries and, more lately, decades to mature the acceleration of our understanding can reduce this time to years, months, or less. A year has passed since Dr. Eugenio Mercuri and colleagues described two siblings with an unexplained severe congenital muscular dystrophy in this Journal [9], and the same group more recently defined this disorder as yet another muscular dystrophy caused by abnormal glycosylation due to mutations in the fukutin-related protein gene [1]. Still more intriguing, the rare disorder turned out to be a quite common disease giving rise also to an allelic milder limb girdle form of muscular dystrophy [2]. Clearly the multiplicity of parallel events tends to reduce our awe and attention for such achievements, fascinating and eye opening as they may be, and the historical struggle for eponymous longevity has at least partially become superceded by the desire for a database entry.

However shortlived our times have become, these anecdotes also illustrate our need for a more profound understanding for our patients and their disorders, and the active role Neuropediatrics will play in this ongoing evolution of concepts in child neurology. This task would be impossible without the continued input, support, and critical advice of the many scientists who support the Editor and the Editorial Board and contribute their knowledge by reviewing manuscripts for the Journal. With all due thanks and sincere appreciation their names are listed below. The Editors also wish to express their gratefulness to the outgoing members of the Editorial Board, Dr. Odile Boespflug-Tanguy, Clermont-Ferrand, and Dr. K.V. Toyka, Würzburg, whose expertise and wisdom have been a valuable guidance over the years. We welcome the new members of the Editorial Board, Dr. Gabriele Gillesen-Kaesbach, Essen, Dr. Kathrin North, Sydney, and Dr. R. Guerrini from London.
A journal is never better than its contents. The Editors are deeply indebted to the many contributors who have shaped the Journal to become a lively and interactive forum. And with a purposeful admixture of history as beautifully illustrated in the recent paper on the great neurologist Oppenheim [6] among all the science with its inherent dryness the bemused chronicler of times may detect one or the other trouvaille among its pages or simply enjoy the pleasure of reading.

Thomas Voit

\section{Reviewers for Neuropediatrics}

G. Anneren, M. Anvret, H.J. Böhles, H.J. Christen, F. Cowan, N. Darin, C. Eggers, J. T. Epplen, M. Forsting, E. Fransen, J. Gärtner, K. M. Gibson, G. Gillessen-Kaesbach, U. Goebel, S. Grünewald, R. Guerrini, B. Hauffa, F. Heinen, N. Herschkowitz, G. Horneff, H. Ikonomidou, J. Jaeken, K. Johnson, B. Jurklies, J. Klepper, R. Korinthenberg, A. Kohlschütter, F. Lehmann-Horn, H. Lochmüller, E. Mercuri, P. Meinecke, K. Müller, A. Munnich, B. A. Neubauer, B. Neville, K. North, U. Nowak-Göttel, A. Percy, H. Pihko, B. Plecko, S. Preis, V.T. Raemaekers, D. Rating, A. Reder, W. Reik, T. O. Rogemann, M. Roggendorf, C. Roll, T. Rosenbaum, B. Rosenblatt, H. Sarnat, O.D. Saugstad, S. Stöckler-Ipsiroglu, U. Schöning, H. Schroten, J. Soul, O. Skeldal, M. Steinlin, U. Stephani, K. Swoboda, V. Straub, I. Tuxhorn, K. Ullrich, J. Valk, C. Wallgren-Pettersen, U. Wendel, M. Wehnert, R. Wewers, E. Wilichowski, M. Zatz, K. Zerres

\section{References}

${ }^{1}$ Brockington M, Blake DJ, Prandini P et al. Mutations in the fukutinrelated protein gene (FKRP) cause a form of congenital muscular dystrophy with secondary laminin alpha2 deficiency and abnormal glycosylation of alpha-dystroglycan. Am J Hum Genet 2001; 69: 1198 1209

2 Brockington M, Yuva Y, Prandini P et al. Mutations in the fukutinrelated protein gene (FKRP) identify limb girdle muscular dystrophy 2I as a milder allelic variant of congenital muscular dystrophy MDC 1 C. Hum Mol Genet 2001; 10: 2851 - 2859

${ }^{3}$ Burck U, Goebel HH, Kuhlendahl HD et al. Neuromyopathy and vitamin E deficiency in man. Neuropediatrics 1981; 12: 267-278

${ }^{4}$ Cormand B, Avela K, Pihko H et al. Assignment of the muscle-eyebrain disease gene to 1 p32-p34 by linkage analysis and homozygosity mapping. Am J Hum Genet 1999; 64: $126-135$

${ }^{5}$ Harding AE, Matthews S, Jones S et al. Spinocerebellar degeneration associated with a selective defect of vitamin E absorption. New Engl J Med 1985; 313: 32 - 35

${ }^{6}$ Hoeltzenbein M, Tomé FMS. Oppenheim’s Myatonia Congenita. Neuropediatrics $2001 ; 32: 57-61$

${ }^{7}$ Hoffman EP, Brown RH, Kunkel LM. Dystrophin: the protein product of the Duchenne muscular dystrophy locus. Cell 1987; 51: 919-928

${ }^{8}$ Meryon E. On granular and fatty degenerations of the voluntary muscles. Medico-Chirurg Transact 1852; 35:73-84

${ }^{9}$ Mercuri E, Sewry CA, Brown SC et al. Congenital muscular dystrophy with secondary merosin deficiency and normal brain MRI: a novel entity? Neuropediatrics 2000; 31: 186-189

${ }^{10}$ Ouahchi K, Arita M, Kayden $\mathrm{H}$ et al. Ataxia with isolated vitamin E deficiency is caused by mutations in the alpha-tocopherol transfer protein. Nat Genet 1995; 9: $141-145$

${ }^{11}$ Raitta C, Lamminen M, Santavuori P, Leisti J. Ophthalmological findings in a new syndrome with muscle, eye and brain involvement. Acta Ophthalmol 1978; 56: 465-472

12 Santavuori P, Leisti J, Kruus S. Muscle, eye and brain disease: a new syndrome. Neuropädiatrie 1977; 8: 533

${ }^{13}$ Yoshida A, Kobayashi K, Manya $\mathrm{H}$ et al. Muscular dystrophy and neuronal migration disorder caused by mutations in a glycosyltransferase, POMGnT1. Dev Cell 2001; 1: $717-724$ 